\title{
The Influence of Judicial Centralism on the Work of Investigation and Evidence Collection
}

\author{
$\mathrm{Ke} \mathrm{Wu}$ \\ Wuhan University of Science and Technology \\ Wuhan, China
}

\begin{abstract}
The judicial centralism has abandoned the disadvantages of the court trial illusive establishment under the investigative centralism, and the evidentiary adjudication principle has been carried out to the whole process of the criminal procedure, and forced the investigation organ to carry out the investigation work according to law. This paper will explore how the investigation organs improve detection capabilities, actively respond to the higher requirements of the judicial centralism to the evidentiary adjudication from the aspects that shall not force self incrimination, adhere to the illegal evidence exclusion and direct oral evidence, strictly follow the standard of proof and improve the technical level of investigation etc.
\end{abstract}

Keywords-judicial centralism; investigation; evidence collection

\section{THE SUMMARY OF THE JUdICIAL CENTRALISM}

\section{A. The Connotation of Judicial Centralism}

Judicial centralism is a judicial principle which is widely recognized by modern judicature. The connotation of the judicial centralism can be explained from two aspects. First of all, judicial centralism means that in the longitudinal movement of investigation, prosecution and trial procedure, trial procedure is the center of the whole criminal procedure, also the key and final link of conviction and sentencing to criminal cases. In other words, at the entity level, the people's court is the only conviction and sentencing authority; at the program level, the collected evidence and identified facts of the investigation and prosecution must be confirmed by the trial of the people's court before it can be taken as a verdict. Thus it can be seen that, judicial centralism is a theoretical concept drawn from the judicial procedures and investigation, review and prosecution procedures through the longitudinal comparison research, which is a proposition in the field of criminal procedure. Secondly, from the point of view of the horizontal operation of the trial procedure itself, the trial is the center of the trial procedure. All the evidence must be presented in court, after the court investigation and debate, full cross examination, the judge shall make the court decision according to the certified evidence. Based on this, it should pay special attention to the role of first instance procedure. As the most basic, the most complete and the core of the trial procedure, the first instance should highlight its position and function in the whole trial stage.

\section{B. The Present Situation and Drawbacks of the Criminal Procedure of Our Country}

Corresponding to the judicial centralism is the investigation centralism, some scholars also call the dossier deportation centralism. The investigation centralism is the factor that restricts our country to deepen the reform of the judicial system in the long term. Investigation centralism is, in essence, that takes the procedure of investigation as the center of criminal procedure. "The punishment of crime" has become the sole task of criminal litigation. Prosecution and trial procedure illusive establishment, , criminal procedure are the confirmation procedures for the investigation files material, especially investigation records.

Affected by influence of the long feudal culture and feudal judicial tradition and the wrong guidance of "heavy punishment for the crime, neglecting the safeguard human rights", "heavy entity, light procedure" and other obsolete judicial philosophy, the "assembly line" type of litigation mode in our country presents the strong position of the investigation organs and the weak position of the procuratorial organs and the judicial organs in the long period of judicial practice. Especially the public security organ, which is the main investigative organ in the criminal procedure, has the dual legal status. It is the administrative organ and the judicial organ. Because of the long term feudal operation mode of the unity of administration and justice, the public security organs have the political status and investigation of technical means that the judicial organs can not match. Although the criminal procedure law clearly stipulates that three public security organs should cooperate and restrict with each other, however, in judicial practice there are more cooperation but less restraint The exercise of investigation power has no substantive legal restraint mechanism, which led to the dominant position of the public security organs. For the evidence and facts collected and found by the public security organs, the people's procuratorate and the people's courts rarely play review gatekeeper function, and trial procedure often is to go through the motions, the investigation becomes the center of the whole criminal procedure

The issues that the investigation power is too strong, the procuratorial and judicial force is insufficient, court trial is illusive establishment etc., caused by investigation centralism lead to the occurrence of extorting a confession by torture and the miscarriages of justice, serious harm to the litigation rights of the criminal suspects and defendants, also erode the judicial 
justice and social credibility. Especially in recent years, the network gradually exposed major miscarriages of justice, which even led to the deep reflection of the theoretical circle and the country on the criminal litigation system. The reform of criminal procedure in our country is showing the trend of investigation power suppression, procuratorial power and judicial power restricting and balancing the investigation power, to make the criminal trial hold the last defense line of the judicial fair.

Investigation procedures as the most critical pre-trial procedures, has an irreplaceable significance to collect evidence, identify the facts of the case, realize judicial justice. Therefore, under the background of the reform of judicial centralism, how the investigation authorities deal with the new requirements and high standards proposed by the trial procedure, how to prosecute criminals more accurately under the circumstance that the criminal evidence rule forces evidence collection procedures, are the major issues that the investigation organs must face.

\section{THE REQUEST OF JUdiCIAL CENTRALISM TO THE} PRINCIPLE OF EVIDENTIARY ADJUDICATION APPLICABLE TO THE INVESTIGATION ORGANS

\section{A. The Requirements of the Principle of Evidence Judgment}

The mode of judicial centralism litigation has put forward higher requirements on the identification of criminal facts, the system of evidence and the quality of evidence etc.. In a certain sense, to realize the judicial centralism, the most critical is to implement the principle of evidentiary adjudication in all aspects of criminal procedures.

Adherence to the principle of evidentiary adjudication must follow the requirements of the evidence rule system: (1) fully emphasize the evidence ability. The so-called evidence ability is the qualification of evidence, that is, the qualification that allows to investigate and adopt the case materials as evidence. This is the normative meaning of the evidence as the basis of judgment. (2) clearly distinguish between legal facts and objective facts. To clearly distinguish between objective facts and legal facts, to make the court decision on the basis of legal reasoning, is the respect to the human rights of the defendants and the judicial principles, also the necessary prerequisite for the realization of substantive justice. (3) follow the confession corroboration rule. The criminal procedure law of our country regulates that, only the suspect's confession can not be convicted of sentencing. (4) guarantee the witnesses and appraisers to appear in court. The principle of evidentiary adjudication requires the court to conduct a cross examination of evidence, which is especially important for the verbal evidence. (5) clear the proof standard. The principle of evidentiary adjudication requires that according to all the evidence with evidence ability comprehensively judge if the determination of the facts of the case reaches the statutory certification standard.

\section{B. The Specific Requirements of Judicial Centralism to the Principle of Evidentiary Adjudication Applicable to the Investigation Organs}

Judicial centralism has put forward new requirements to the investigation organ's investigation and evidence collection. To improve the quality of detection work and the ability to deal with the court trial, to realize the civilized investigation, to carry out the principle of evidentiary adjudication by investigation organs has become a top priority. They must adhere to the requirements that shall not force the self incrimination, fully implement the principle of directness and verbalism, strictly enforce the system of illegal evidence exclusion and the proof standard of criminal procedure etc.

1) The judicial centralism requires that the investigation organ shall not force the self incrimination: The principle of evidentiary adjudication requires that all investigation actions of the investigation authorities must speak and act according to the evidence. Evidence here must be the evidence chain which is able to prove the facts of the crime, enough to make the judges reach the inner conviction. Article 5 of China's Law of Criminal Procedure stipulates that no person shall be forced to prove himself to be guilty, which has the substantial homology with the system of silence right of the law developed western countries. It is the necessary righteousness to carry out the innocent presumption. But in judicial practice, the evidence awareness of the investigation staff is always weak, who tend to ignore the principle of evidentiary adjudication and the requirements of criminal procedure law, adhere to the supremacy of confessions, leading to the prevailing of extorting confessions by torture.

This investigative mode of confession first and evidence later with interrogation as the center, not only makes the act of investigation and the evidence collected at the investigation stage unable to bear the test of the court review, increases the detection risk under the requirements of judicial centralism, also seriously violates the human rights of the criminal suspect and the principle of procedural justice. Therefore, the investigation organ shall be in full compliance with the principle of evidentiary adjudication, abandon the evidence ideology of confession centralism, respect the procedural rights of the criminal suspect, not force the self incrimination of the criminal suspect, in order to truly improve the ability to collect evidence and deal with the court trial.

2) The judicial centralism requires that the investigation organ shall fully implement the principle of directness and verbalism: The principle of directness and verbalism is a collection of the directness principle and the verbalism principle. The directness principle or the principle of directness hearing, refers to that the judge takes the evidence materials with direct access in person in the court trial as the judicial basis. The directness principle requests for the continuity of the trial, the identity of the hearing judge and the verdict judge, at the same time requires: except the regulations of law, when the case is tried the public prosecutor, the parties and other litigant participants shall be at present, all types of evidence shall be presented for the cross 
examination in court so as to exclude hearsay evidence. The verbalism principle or the principle of verbalism hearing refers to that presenting proof, cross examination and debate and other activities of the litigation parties and litigant participants shall be oral presentation. The opposite of verbalism trail is documentary hearing with investigating files as the center. As a matter of fact, the principle of directness and verbalism has the inherent unity.

China's Criminal Procedure Law has not clearly established the principle, but it reflects the requirements of the principle. The application of the principle of directness and verbalism in the criminal procedure proposes the requirements of substantive review to the evidence and the testimony of witnesses, also puts forward the new demands to the investigation organs and personnel on the legitimacy of evidence sources and evidence collection procedure, the force of evidence and admissibility, the integrity of the evidence chain, the strain capacity of court trial and other investigation and evidence collection and handling quality. For example, for the controversial testimony of witnesses or expert opinions which have important significance to the verdict, if the witness and appraisers do not appear in the court without justifiable reasons, the written testimony and expert opinions provided by the investigation organs shall not be as the verdict basis. This requires the investigation organ to consider the possible influence whether the witnesses and appraisers appear in the court on the evidence system and the verdict. For example, the principle of directness and verbalism brings the strengthening of court antagonism, the traditional evidence collection mode over reliant on oral confession is difficult to deal with the risk of the defendant's retraction of confession in the court trial. Therefore, the investigation organ must fully implement the requirements of the principle of directness and verbalism, not only to collect evidence, but also to strengthen the evidence examination, refine the review standards, and clear the review responsibility, change the investigation mode of "confession first and evidence later" to "evidence first and confession later", implement the evidence idea based on real evidence and supplemented by oral evidence, pay attention to the collection and preservation of material evidence, documentary evidence and electronic evidence and other objective evidence.

3) The judicial centralism requires that the investigation organ shall legally collect evidence, strictly enforce the illegal evidence exclusion system: In 2010, the Regulations on Several Issues concerning the Exclusion of Illegal Evidence in Criminal Cases jointly issued by "two supreme and three departments" clears that the testimony obtained by torture and other illegal means can not be served as verdict basis, and makes specific provisions for the procedures of reviewing and excluding illegal evidence, proof responsibility and interrogators in court and other problems. In 2012, the new Criminal Procedure Law inherited and developed the illegal evidence exclusion system from the basic law. Illegal evidence exclusion system provides a powerful weapon for defense against the prosecution, which contributes to the court review of the evidence, guiding the investigation organs to improve the awareness of protecting human rights and legally collecting evidence, so as to ensure the legitimacy of evidence.

To strictly enforce the illegal evidence exclusion system, the investigation organs shall also change the obsolete judicial philosophy such as "heavy punishment for the crime, neglecting the safeguard human rights", "heavy entity, light procedure", presumption of guilt, not only to "find facts", but also to "prove facts", strengthen the evidence awareness. Establish the criticality concept of the physical evidence and the complementatrity concept of oral confession on the basis of extensive collection and timely preservation of evidence. Especially in the specific matters such as the adoption of the compulsory measures, the whole preservation of the interrogation video recording, prevent the risks brought by the illegal evidence exclusion system.

Although the illegal evidence exclusion system of China is imperfect, the investigation organ shall still conform to the trend of the development of judicial reform, strictly restrict their own investigation behavior, uphold the legitimate evidence collection, to successfully deal with the challenges brought by the reform of judicial centralism.

4) The judicial centralism requires that the investigation organ shall strictly enforce the proof standard of criminal procedure: Article 160 of China's Criminal Procedure Law regulates the proof standards of ending investigation and transferred to lawsuit: the cases with conclusion of investigation by the public security organs shall clear the facts of the crime, with true and sufficient evidences. Some scholars believe that, China's Criminal Procedure Law regulates that transferring to lawsuit, public prosecution and conviction are commonly applied to the proof standard "clear fact, true and sufficient evidence", which violates the materialism epistemology and criminal law. Applying the same high standards of the guilty verdict to the investigation conclusion, makes the court trial become a mere formality, which plant the seeds for the occurrence of miscarriages of justice. Put forward the establishment of progressive criminal proof standards. From the conclusion of the investigation to the prosecution to the court verdict of guilty, the proof standards gradually improve, which is consistent with rule of criminal procedure, consistent with the requirements of investigation serving the trail proposed by judicial centralism. Based on this, the judicial practice of our country has put forward to use "two basic" proof standards in the investigation stage, namely "the basic facts are clear and the basic evidences are sufficient". However, this formulation can not solve the problem of the fuzzy concept "basic". In the practice, it evolves to "the evidences are basically clear and the facts are basically sufficient", reducing the proof standards and the quality of handling case.

Although the above-mentioned proposals by scholars have some truth, but in the framework of the existing legal system, the proof standards on the conclusion of investigation can still make the interpretation in accordance with the rules of criminal procedures. The determination of "clear criminal facts, true and sufficient evidence" for the conclusion of 
investigation shall be the unilateral determination of the investigation organs affected by its litigation function and status. This kind of guilty bias derives from the state prosecution status of the investigation organ, which is not the same as the proof standards to make guilty verdict. It also does not exclude that the court can make a verdict of not guilty after the trial. But the proof standards of the conclusion of investigation also put forward objective demands to the evidence collection of the investigation organs, namely, guarantee the objectivity and adequacy of evidence and abandon confession centralism, form the effective evidence chain. The proof standards of "subjective" clear facts, true and sufficient evidence in the investigation stage are in consistent with the characteristics of the litigation stage. The investigation is to investigate and collect evidence for the prosecution and prepare for the public prosecutor to open the trial procedures. Therefore, the identification of criminal liability of the investigation and prosecution procedure about reaching the stage proof standards only has the procedural meaning, without verdict effect of guilty or not guilty. For the true and sufficient evidence required by the guilty verdict, Article 53 of Criminal Procedure Law made specific requirements, that true and sufficient evidence shall meet the following conditions: (1) conviction and sentencing facts have evidence; (2) the evidences that could be used to determine a case shall be verified by the statutory procedures; (3) integrate the whole case evidence, to affirm the fact beyond a reasonable doubt. The new criminal procedure law introduces the inner conviction standard "ruling out reasonable doubt", to form the proof standard with integration of objectivity and subjectivity of the guilty verdict, to further illustrate the internal arrangement and asymptotic property of proof standards in the different stages of criminal procedures.

5) The judicial centralism requires that the investigation organ shall optimize the technology of obtaining evidence and the ability to deal with the trial: In judicial practice, investigation and obtaining evidence of the investigation organ takes confession as the center in the long term. The core of investigation and evidence collection is concentrated in the interrogation, leading to the insufficient ability of criminal evidence collection, or even resulting in the loss of evidence ability. Especially with the increasingly complex social environment, new crimes and cross regional crimes are increasing, the investigation organs' technical means of collecting evidence shall conform to the time request. They shall carry forward the traditional advantages, at the same time, actively update investigation technologies, introduce network information detection method and the public security information technical means, establish a unified sharing national population information database, establish cross regional investigation cooperation management mechanism, cultivate scientific investigation thinking and philosophy, improve the capacity, efficiency and quality of evidence collection. Making full use of high technology to realize the "intensify the police by technology" is urgent, but it is also necessary to regulate the technical means according to the law, to avoid the greater troubles brought by the abuse of investigation technologies to violate human rights.

\section{REFERENCES}

[1] Sun Changyong. Judicial Centralism and Its Influence on Criminal Procedure [J]. Modern Law Science, 1999 (08) 93-97.

[2] Chen Weidong. To Promote the Reform of Litigation System with Judicial Centralism [N]. Chinese Social Sciences Weekly, 663rd, October 31, 2014.

[3] Gu Yongzhong. My Opinion onCourt Hearing Centralism [N]. People's Court Daily, 2014-05-16.

[4] Long Zongzhi, On the Establishment of Fact Identification Mechanism with the First Criminal Trial as the Center [J]. China Law, 2010 (2).

[5] Shen Deyong. The Basic Direction of the Reform and Development of Criminal Judicial Procedure [N]. People's Court Daily, 2014-10-24

[6] The Party's Fourth Plenary Session of the 18th CPC Central Committee $<$ Decision>Hundreds of Questions of Learning and Counseling. Party Building Reading Publishing, 2014 Edition

[7] Zhang Jianwei. The Substantive Connotation and the Realization Way of Judicial Centralism [J]. Chinese and Foreign Legal Science, 2015 (4).

[8] Huang Zhenggang. On the Investigation Reply under the Construction of "Judicial Centralism"[J]. The Public Security Education, 2015 (10).

[9] Zhang Jianwei. The Essence and Representation of Judicial Centralism [N]. People's Court Daily, 2014-06-20.

[10] Tang Xuelian. On the Influence of Judicial Centralism on the Investigation Work of China[J]. Journal of Sichuan Police College, 2014 (6).

[11] Fan Chongyi. On the Litigation System Reform of Judicial Centralism [J]. Zhongzhou Academic Journal, 2015 (1).

[12] Zhu Xiaoqing. A Brief Discussion on "Judicial Centralism"[J]. The People's Procuratorate, 2015 (1).

[13] Chang Linzhu, Zhang Zhong. Evidence Theory and Science: the Fourth International Conference Proceedings, China University of Political Science and Law Press (2014) 112 - 122.

[14] Wu Hongqi. Reflection on the Principle of Evidentiary Adjudication in the Context of the Judicial Centralism [J]. Theoretical Perspective, 2015 (4).

[15] Chen Guangzhong. A Discussion on Some Problems of the Principle of Evidentiary Adjudication [N]. Journal of the Party Committee School of Zhejiang Province, China, (2014) (6).

[16] Chen Ruihua. Law of Criminal Evidence Law [M]. Peking University Press, 2014.

[17] Wang Yajing. On the Transformation of Investigation Mechanism to Judicial Centralism [J]. Journal of Hubei Police College, 2015 (11).

[18] Fan Zixiong, Xu Xu. An Investigation of the Problems Existing in the Evidence Collection and Examination of the Investigation Organs hppt://www.scfzw.net/lfdt/html/82-1/1546.htm

[19] He Jiahong. From Investigation Centralism to Judicial Centralism -- the Improvement of China's Criminal Procedure System [J]. Social Sciences in Chinese Universities, 2015 (2). 